\title{
A Time-Series Record during COVID-19 Lockdown Shows the High Resilience of Dissolved Heavy Metals in the Ganga River
}

\author{
Tanuj Shukla, Indra S. Sen,* Soumita Boral, and Sanjeet Sharma \\ Cite This: https://dx.doi.org/10.1021/acs.estlett.0c00982 \\ Read Online
}

Supporting Information

ABSTRACT: The world's large rivers have been intensely studied to better understand the impact of climate change and direct human interventions on river water quality and quantity. Of particular importance is the extent to which industrial, domestic, and agricultural discharges are modifying the dissolved inorganic constituents (major elements, trace elements, nutrients, and heavy metals) of large river systems vis-à-vis water quality. The COVID-19 pandemic lockdown provides a rare opportunity to quantify the impact of restricted anthropogenic activities on the water chemistry resilience of large rivers. By analyzing the daily geochemical record of the Ganga River, we demonstrate that reduced industrial discharge during 51 days of mandated nationwide lockdown decreased the dissolved heavy metal concentrations by a minimum of $50 \%$. In contrast, nitrate and phosphate inputs predominantly derived from agricultural runoff and domestic sewage maintained a chemical status quo as these sources were not impacted by the nationwide confinement or their residence time was longer than the characteristic time of the perturbation. We demonstrate the high resilience of dissolved heavy metals and conclude that industrial wastewater minimization programs will substantially improve heavy metal pollution of the Ganga River in a short time span of a few months.

\section{INTRODUCTION}

Time-series geochemical records of river water tell us about the processes occurring in the river's watershed. River water chemistry is therefore monitored globally at various spatial and temporal scales to assess the intensity and scope of global water quality challenges. ${ }^{1-3}$ River monitoring studies suggest that the chemical composition of river water in densely populated regions has deteriorated globally since the 1990s. ${ }^{4,5}$ A recent assessment of global rivers ${ }^{6}$ shows that water quality in $>80 \%$ of the world's transboundary rivers, including several large river systems, is severely affected by nutrient contamination (mainly nitrogen and phosphorus), e.g., in the Rhine, Danube, and Indus rivers, and wastewater pathogens (largely human waste), e.g., in the Amazon, Nile, Congo, Yenisey, Niger, Amur, Indus, Ganga, Brahmaputra, Salween, and Mekong rivers. ${ }^{5}$ Despite the magnitude of the issue, the resilience of water quality to human actions over shorter time scales is underexplored but is critically important for protecting and restoring river water quality to achieve sustainable development goals for health, food, and water security.

Water quality is a particularly major concern in the densely populated (390 people $\mathrm{km}^{-2}$ ) and heavily polluted ${ }^{7}$ Ganga Basin, home to 0.4 billion people. ${ }^{8}$ Previous studies of the Ganga Basin have produced a rich body of information about the role of bedrock weathering processes in river water composition, $^{9-14}$ land to ocean sediment and chemical fluxes, $^{10,15-21}$ and the status of typical water quality parameters, $^{22}$ namely, chemical and biochemical oxygen demand (BOD and $\mathrm{COD}$, respectively), dissolved oxygen
(DO), $\mathrm{pH}$, total coliform (TC), and fecal coliform (FC), highlighting the importance of silicate-carbonate rock weathering in river chemistry, the effect of land to ocean chemical fluxes on marine records, and the importance of wastewater pathogens in the river basin, ${ }^{23-26}$ respectively. In addition, concerns have also been raised about increasing concentrations of dissolved inorganic constituents, including the toxic heavy metals ( $\mathrm{V}, \mathrm{Cr}, \mathrm{Co}, \mathrm{Cu}$, and $\mathrm{Ni}$ ), and their impact on water quality and river ecology. ${ }^{7,27}$ However, the resilience of dissolved heavy metals, nitrate $\left(\mathrm{NO}_{3}{ }^{-}\right)$, and phosphate $\left(\mathrm{PO}_{4}{ }^{2-}\right)$ concentrations to short-term human actions is unknown.

The COVID-19-mandated 51 days of nationwide lockdowns of all but essential services in India provided a unique opportunity to quantify the resilience of river water chemistry in terms of sudden human actions. ${ }^{28,29}$ The lockdowns resulted in a complete shutdown of industrial operations, and in turn, the effluent discharge from various industries was negligible. This industrial discharge usually ends up in nearby water bodies and groundwater ${ }^{26}$ despite India's stringent "zero liquid discharge" laws preventing discharge of untreated effluent in

Received: December 17, 2020

Revised: January 19, 2021

Accepted: January 20, 2021 
rivers. $^{22}$ It is estimated that industrial wastewater contributes nearly $20 \%$ of the total volume of wastewater generated in the Ganga Basin $^{30}$ and its near absence is undoubtedly a rare opportunity to quantify the resilience of water quality parameters.

Here we report the daily geochemical records of the Ganga River (Tables S1 and S2) at Prayagraj downstream of the Yamuna confluence $\left[25.40^{\circ} \mathrm{N}, 81.90^{\circ} \mathrm{E} ; 98 \mathrm{~m}\right.$ above sea level (hereafter m.a.s.l.)] in the state of Uttar Pradesh between March 25, 2020, and May 13, 2020. The study site, although not representative of the entire Ganga Basin (Figure S1), fits our study objective because the immediate upstream stretch of the study site is considered to be the most polluted ${ }^{31}$ owing to the presence of multiple industrial centers, including the "Leather City of the World". We emphasize that of the 764 industries in the entire Indian part of the Ganga Basin, 90\% of the industries are located in the state of Uttar Pradesh alone, consisting mostly of tanneries (64\%) and textile (9\%), sugar $(8.2 \%)$, and paper (4.8\%) industries. ${ }^{32}$ Even in terms of industrial wastewater generation, Uttar Pradesh also leads all other states in the Ganga Basin, generating 269 million liters per day (MLD), which is $54 \%$ of the total wastewater generated in the entire basin. As a result, the stretch of the Ganga river upstream of Prayagraj always reports the highest concentrations of trace metals, which become diluted downstream by joining of large tributaries, namely, the Ghaghara, Son, Gandak, and Kosi rivers. ${ }^{31}$

\section{MATERIALS AND METHODS}

River water samples were collected from freely flowing surface water for all time points. We used a hand-rowed wooden boat to collect water samples away from the river banks. It is important to highlight that we have sampled only the surface water, keeping in mind that there may be some chemical heterogeneity in the water column. The samples were filtered on site using an all-plastic [polypropylene (PP) and polyethylene $(\mathrm{PE})]$ syringe using a Sterivex cartridge $[0.22 \mu \mathrm{m}$ pore size polyethersulfone membranes from Millipore]. The filtered water samples were collected in precleaned $1 \mathrm{~L}$ and 125 $\mathrm{mL}$ high-density polyethylene (HDPE) bottles. The $1 \mathrm{~L}$ bottle was acidified to $\mathrm{pH} \sim 2$ (doubly distilled $\mathrm{HNO}_{3}$ ), whereas the $125 \mathrm{~mL}$ bottles were frozen within $2 \mathrm{~h}$ of sample collection and used for major-ion analysis. It is important to mention that the "dissolved" fraction includes both the truly dissolved fraction $(<0.001 \mu \mathrm{m})$ and the colloidal fraction $(0.001-0.22 \mu \mathrm{m})$. All of the samples collected during the lockdown events have been registered in the System for Earth Sample Registration database (www.geosamples.org) with a unique International Geo Sample Number (ISGN) that can be used to retrieve the sample metadata. Additional pre-COVID-19 period samples studied here (Table S3) are from the Boral et al. ${ }^{31}$ now housed at the Indian Institute of Technology Kanpur. Dissolved major ions (Table S1) and trace element concentrations (Table S2) were measured using an ion chromatograph (IC) and a triple quadrupole inductively coupled plasma mass spectrometer (QQQ-ICP-MS) at the Department of Earth Sciences of the Indian Institute of Technology Kanpur. The Supporting Information gives more details about the measurement protocols of IC and QQQ-ICP-MS, and data quality assurance and quality control.

Discharge data were obtained from River and Reservoir Watch version 3.8 using the database of the Dartmouth Flood Observatory. The discharge data are satellite microwave radiometry measurements at $25.244^{\circ} \mathrm{N}, 82.395^{\circ} \mathrm{E}$, which is downstream of the confluence between the Yamuna and Ganga rivers, and $\sim 50 \mathrm{~km}$ downstream of our sampling site (Figure S1). The remotely sensed discharge data were validated with global runoff models (WBM models), ${ }^{33}$ as nearby gaugingbased discharge data were unavailable. The accuracy assessment of the WBM modeling and remotely sensed discharge data reveals a Nash-Sutcliffe efficiency of $>0.44$, where an efficiency of $1(E=1)$ corresponds to a perfect agreement between both methods. ${ }^{34}$ Because discharge data have large uncertainties, we further calculated the daily amount of precipitation in the catchment upstream of our sampling site. We calculated the amount of daily rainfall during the study period for the Yamuna, Chambal, Betwa, and Ken [tributaries upstream of the sampling site (Figure S1)] catchment, as well as the Ganga River using daily rainfall values from CHIRPS (Climate Hazards Group InfraRed Precipitation with Station) daily data, version 2.0. ${ }^{35}$ The tributary catchment polygons were defined topographically using the "Watershed" cloudbased geoprocessing tool in ArcGIS (Esri Corp.). Rainfall data at each tributary catchment were summed to obtain the catchment daily precipitation upstream of our sampling site. ${ }^{31}$ The discharge and amount of daily precipitation in the catchment are listed in Table S1.

\section{RESULTS AND DISCUSSION}

The major ions (except $\mathrm{NO}_{3}{ }^{-}$and $\mathrm{PO}_{4}{ }^{2-}$ ) and trace elements (e.g., $\mathrm{Rb}, \mathrm{Sr}, \mathrm{Li}$, and $\mathrm{As}$ ) exhibit temporal variability, and their concentrations are quite similar to premonsoon (March to May) pre-COVID-19 concentrations. ${ }^{31}$ In general, $\mathrm{Rb}, \mathrm{Sr}, \mathrm{Li}$, and As concentrations increased with time, that of $\mathrm{Ca}^{2+} \mathrm{did}$ not, and concentrations of $\mathrm{V}, \mathrm{Cr}, \mathrm{Co}, \mathrm{Ni}$, and $\mathrm{Cu}$ do not show any systematic temporal trends (Table S1, S2 and Figure S2). Concentrations of trace elements such as $\mathrm{Rb}, \mathrm{Sr}, \mathrm{Li}$, and $\mathrm{As}$ show strong to moderate positive correlations with each other, as well as with the major ions (Table S4). We emphasize that $\mathrm{Li}$ and As are emerging aqueous contaminants mostly derived from Li-ion batteries (LiBs) ${ }^{36}$ and pesticides, respectively. However, large anthropogenic sources of $\mathrm{Li}$ are absent in the studied catchment, ${ }^{32}$ and As fluxes from mining activities, burning of fossil fuels, use of pesticides, and wood preservatives are small compared to their corresponding geogenic flux. ${ }^{37}$ Therefore, we suggest that $\mathrm{Rb}, \mathrm{Sr}, \mathrm{Li}$, and As are predominantly sourced from common weathering processes, which is evident from their correlations, and are geogenic in nature. ${ }^{38}$ Conversely, the mobility of $\mathrm{V}, \mathrm{Cr}, \mathrm{Co}, \mathrm{Ni}$, and $\mathrm{Cu}$ is low during weathering (cf. Figure 2 of ref 38 ), and therefore, higher concentrations of dissolved heavy metals in rivers are mostly derived from various anthropogenic sources. ${ }^{38}$ Spearman correlation analyses indicate that the heavy metals do not show any strong intracorrelation and indicate the relationship with major and geogenic trace elements (Table S4). It is worth mentioning that here we used the Spearman correlation as the data have a non-normal distribution as revealed by the Kolmogorov-Smirnov test and the Shapiro-Wilk test. The lack of inter-relationships among geogenic trace elements, heavy metals, $\mathrm{NO}_{3}{ }^{-}$, and $\mathrm{PO}_{4}{ }^{2-}$ indicates that they are derived from complex anthropogenic sources (Table S4).

Investigating the temporal variability at a daily scale is a challenging task, because the major and trace elements may have a residence time that is longer than the characteristic time of the perturbation (i.e., a couple of weeks), and as a result, the system would not be able to change unless the perturbation is 


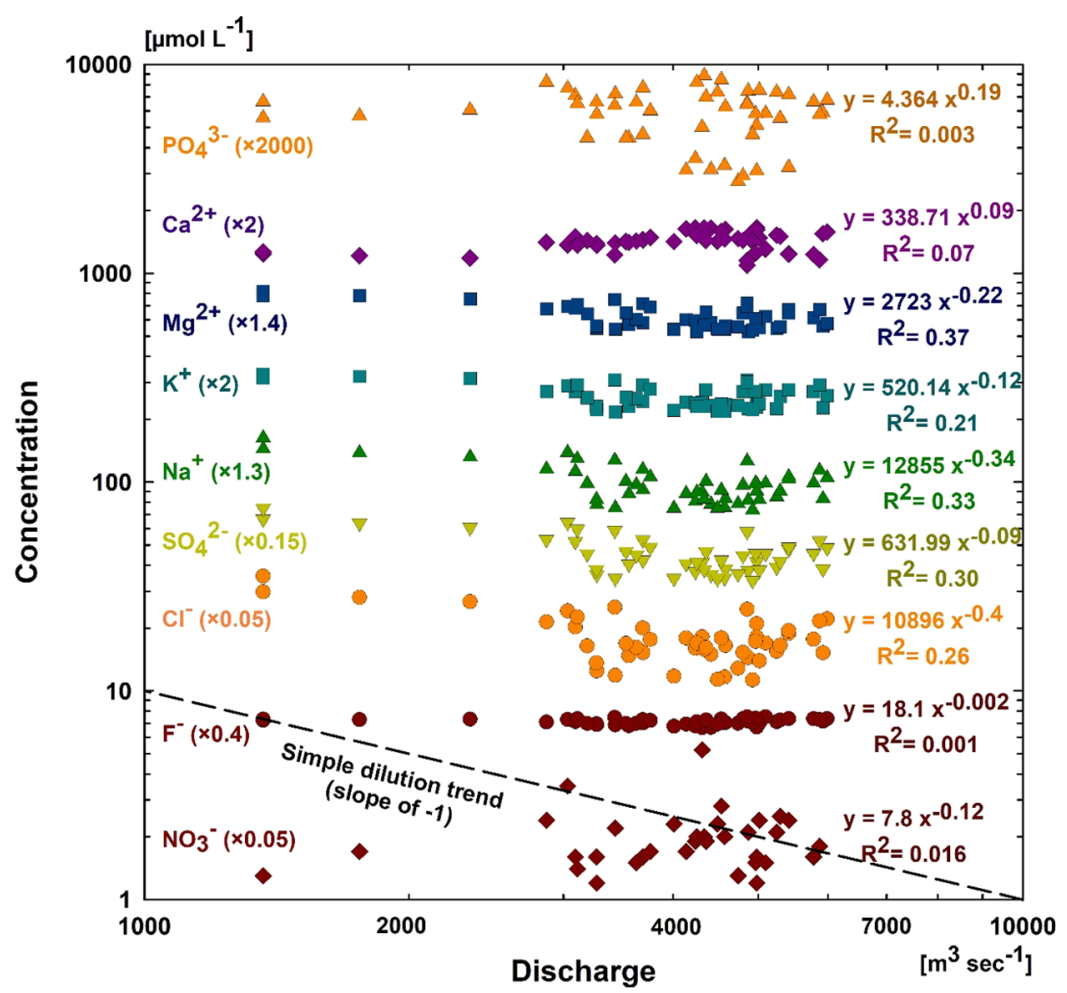

Figure 1. Major-ion concentration variations as a function of discharge plotted in log-log space.

huge. However, we surmise that this is more applicable to the reservoirs that are interacting with the river. For example, groundwater has a very long residence time, and so does water store behind dams. If such reservoirs dominate the flux of an element in a river, they would act as a low-pass filter that will dampen the response of the system. However, this would be significantly more important for the major ions than for trace metals dominated by direct input from anthropogenic sources (direct factory effluent, sewer/stormwater overflow, road runoff, etc.) having negligible residence times. The temporal variability in river chemistry, in particular, the dissolved heavy metal concentrations, therefore may be predominantly explained by variable runoff contributions from different source rocks, the "volumetric effect", in which concentrations are controlled by discharge variability, and by inputs from anthropogenic sources. In the following, we investigate these possible mechanisms.

Variable runoff contributions from silicate- versus carbonatedominated drainage regions could explain some temporal variability in elemental composition, which is evident from the $\mathrm{Sr} / \mathrm{Na}$ versus $\mathrm{Ca} / \mathrm{Na}\left(R^{2}>0.8 ; n=50 ; p<0.001\right)$ and $\mathrm{Ca} / \mathrm{Na}$ versus $\mathrm{Mg} / \mathrm{Na}\left(R^{2}>0.8 ; n=50 ; p<0.001\right)$ molar ratio relationships with time (Figure S3). These element ratios could be affected by ion-exchange reaction, ${ }^{39}$ anthropogenic contamination, and potential sinks such as utilization by plants, but weathering reactions dominate in most cases. The variability in plots of $\mathrm{Sr} / \mathrm{Na}$ versus $\mathrm{Ca} / \mathrm{Na}$ versus $\mathrm{Mg} / \mathrm{Na}$ cannot explain the temporal variation in many of the trace metals as they do not correlate with major ions. For example, the statistical correlations between $\mathrm{Ca} / \mathrm{Na}$ and heavy metals are poor, with resulting $R^{2}$ values of $<0.2(p=0.1)$ for $\mathrm{V}$ and $<0.4(p=0.01)$ for Cr.

To determine the role of discharge in observed temporal variabilities (Figure S2a,b), we calculate the concentration $(C)$-discharge $(Q)$ relationships using the $\log (C)$ versus $\log (Q)$ linear relationships. ${ }^{40,41}$ We calculate the slopes and ordinary least-squares correlation coefficients $\left(R^{2}\right)$ and significance $(p)$ values of $\log (C)$ versus $\log (Q)$ linear relationships. The consistent near-zero $\log (C)$ versus $\log (Q)$ relationship reflects the rate of solute production, and the extent of mobilization is proportional to water flux (chemostat); however, a slope of -1 implies a simple dilution trend. ${ }^{41}$ Figure 1 shows that the calculated slopes for $\mathrm{Na}^{+}, \mathrm{Mg}^{2+}$, and $\mathrm{Cl}^{-}$are $-0.34,-0.22$, and -0.4 , respectively, whereas all other major ions $\left(\mathrm{Ca}^{2+}, \mathrm{K}^{+}, \mathrm{SO}_{4}{ }^{2-}, \mathrm{F}^{-}, \mathrm{NO}_{3}{ }^{-}\right.$, and $\left.\mathrm{PO}_{4}{ }^{2}\right)$ and trace elements $(\mathrm{Li}, \mathrm{Ba}, \mathrm{V}, \mathrm{Cr}, \mathrm{Co}, \mathrm{Ni}$, and $\mathrm{Cu}$ ) show near-zero $\log (C)-\log (Q)$ slopes. Their corresponding statistical correlations are also generally poor, with resulting $R^{2}$ values of $<0.37$. The observed $\log (C)$ versus $\log (Q)$ relationship is similar to previous results (Table S5), e.g., $-0.33 \pm 0.04$ for $\mathrm{Na}^{+},-0.21$ \pm 0.03 for $\mathrm{Mg}^{2+}$, and $-0.36 \pm 0.07$ for $\mathrm{Cl}^{-}$, obtained near the Ganga mouth at Harding Bridge $\left(24.07^{\circ} \mathrm{N}, 80.03^{\circ} \mathrm{E}, 3\right.$ m.a.s.l.) where direct discharge measurement data were used to compute the $\log (C)$ versus $\log (Q)$ relationships. ${ }^{42}$ The near chemostat relationships reflected by shallow slopes and weak correlations in $\log (C)$ versus $\log (Q)$ plots reveal that the temporal variability of major trace elements is not linked to simple dilution but rather to other processes. It is therefore unlikely that the temporal variation of heavy metals, $\mathrm{NO}_{3}{ }^{-}$, and $\mathrm{PO}_{4}{ }^{2-}$ can be explained by changing discharge contributions or variable runoff contributions from different source rocks, implying that other processes control their variation.

As discharge data are derived using the satellite microwave radiometry approach and contain significant uncertainties, ${ }^{33-35}$ we used molar ratios of dissolved elements to remove the discharge dependency on the data set. This will also allow us to capture subtle temporal variability and further compare our data set with pre-COVID-19 elemental concentrations under different hydrologic conditions. Element concentrations were normalized against $\mathrm{Rb}$ (Figure S4) because it has the least 
industrial applications and moderate mobility that is similar to those of the other measured elements. ${ }^{38,43}$ We highlight that normalization with $\mathrm{Rb}$ would not cause any bias as normalizing with other major elements, for example, that of $\mathrm{Na}$ and $\mathrm{Cl}$ that accounts for any evaporation/dilution as well as the extent of water-rock interactions, will generate similar trends (Figure S5). As the identification of the individual anthropogenic source contribution using individual molar ratios will be biased, for example, each element can be derived from more than one anthropogenic source, we plotted the Rb-normalized sum of predominantly geogenic ( $\mathrm{SoG}=\mathrm{Li}, \mathrm{Sr}, \mathrm{Ba}$, and $\mathrm{As}$ ) elements (hereafter termed "SoG/Rb") against the sum of predominantly anthropogenic $(\mathrm{SoA}=\mathrm{V}, \mathrm{Cr}, \mathrm{Co}, \mathrm{Ni}$, and $\mathrm{Cu}$ ) elements (hereafter termed SoA/Rb). Figure S4 shows that $\mathrm{SoA} / \mathrm{Rb}$ decreases with time, whereas $\mathrm{SoG} / \mathrm{Rb}$ shows a nearconstant value because its constituents are weathering-derived and therefore co-vary proportionally. Figure S4 also shows that during the lockdown period, the $\mathrm{SoA} / \mathrm{Rb}$ ratio decreases and trends toward minimal anthropogenically perturbed samples collected at the mountainous catchment of the Ganga river system (average $\mathrm{SoA} / \mathrm{Rb}$ ratio in the mountainous catchment of $1.3 \pm 1.1 ; n=144$; one standard deviation)..$^{31}$ In contrast, $\mathrm{NO}_{3}{ }^{-} / \mathrm{Rb}$ and $\mathrm{PO}_{4}{ }^{2-} / \mathrm{Rb}$ do not show any significant trends (Figure $\mathrm{S} 4 \mathrm{~b}, \mathrm{c}$ ) because $\mathrm{NO}_{3}{ }^{-}$and $\mathrm{PO}_{4}{ }^{2-}$ are predominantly derived from agricultural runoff, and urban and agricultural runoff, respectively, and these sources were not substantially impacted by the nationwide confinement. It is also likely that $\mathrm{NO}_{3}{ }^{-}$and $\mathrm{PO}_{4}{ }^{2-}$ concentrations were more affected by nonpoint discharge via shallow groundwaters that have a longer residence time. In such a scenario, the temporal variability in $\mathrm{NO}_{3}{ }^{-}$and $\mathrm{PO}_{4}{ }^{2-}$ concentrations will be muted and the river system will not be able to change unless the perturbation is substantial. In addition, the stored $\mathrm{NO}_{3}{ }^{-}$and $\mathrm{PO}_{4}{ }^{2-}$ in soil could also dominate the runoff for years, and a brief shutdown of industry/agricultural activities therefore would not impact the dissolved nitrogen and phosphorus load of the Ganga River. A detailed assessment of $\mathrm{NO}_{3}{ }^{-}$and $\mathrm{PO}_{4}{ }^{2-}$ would be required to underpin the temporal variability of the dissolved nutrient load.

To quantify the changes in the dissolved heavy metal concentration load, we determined the change in SoA/Rb with respect to the molar ratios measured during the pre-COVID19 period. $^{31}$ Figure 2 shows that the lockdown during the COVID-19 pandemic decreased the SoA/Rb ratios by $\leq 76 \%$ (Table S2). Because ratios are insensitive to water discharge variability, a decreasing trend in SoA/Rb signifies a decrease in the SoA concentration, which is not controlled by discharge variations. We emphasize that even if we determine the change with respect to the average molar ratios obtained during the first 5 days of nationwide lockdown, which is an approximate lag time required for a pollutant to travel $\sim 300 \mathrm{~km}$ to the sampling site assuming a water velocity of $0.75 \mathrm{~m} \mathrm{~s}^{-1}$ during the nonmonsoon period, ${ }^{16}$ the result still shows a $50 \%$ decrease. Similarly, SoG/Rb ratios on average decreased by $5.5 \%$ (Table S2), which is mostly likely due to variable source rock runoff contributions (Figure S6). We acknowledge that the choice of pre-COVID-19 elemental concentration levels will determine the absolute fractional change; however, the changes are substantial, and the conclusion of the study remains unchanged.

We therefore conclude that the Ganga River has a high resilience toward dissolved heavy metal concentrations and that the river system would revert toward pristine dissolved

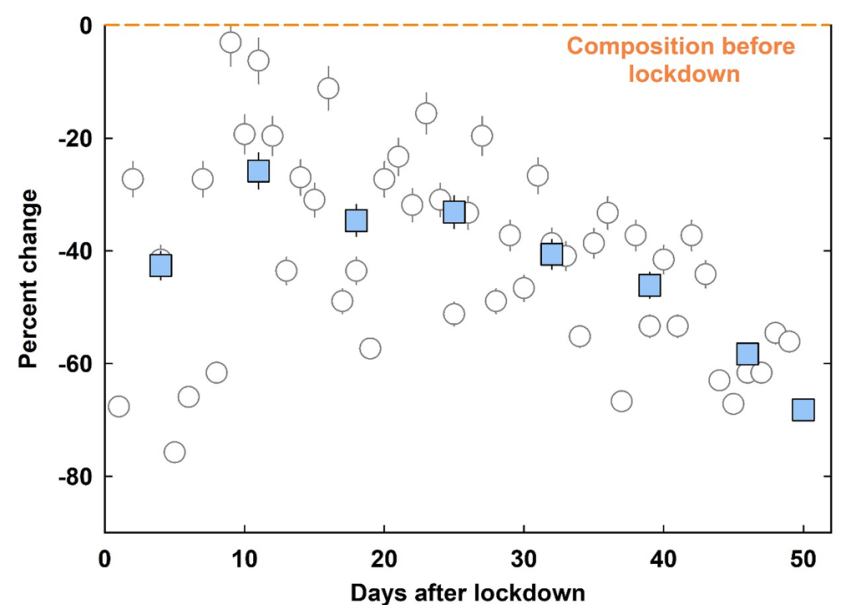

Figure 2. Effect of lockdown restrictions on dissolved trace metals (V, $\mathrm{Cr}, \mathrm{Co}, \mathrm{Ni}$, and $\mathrm{Cu}$ ). The percent changes were calculated with respect to the pre-COVID-19 $(\mathrm{V}+\mathrm{Cr}+\mathrm{Co}+\mathrm{Ni}+\mathrm{Cu}) / \mathrm{Rb}$ ratios. ${ }^{31}$ We set up a range (6-7) for the pre-COVID-19 period by providing $\pm 10 \%$ variability of the average $(\mathrm{V}+\mathrm{Cr}+\mathrm{Co}+\mathrm{Ni}+\mathrm{Cu}) / \mathrm{Rb}$ Ganga river composition $(6.15 ; n=131){ }^{31}$ The percent change for each river water sample was then calculated 10000 times against data randomly selected from a uniform distribution of the pre-COVID-19 range. Each circle reports the mean of all 10000 iterations, and one standard deviation was considered as the uncertainty (error bar). The filled squares denote the weekly averages.

heavy metal concentrations in a short time span of a few months following reductions of industrial wastewater discharge. We further emphasize that COVID-19 lockdown improved only the dissolved heavy metal load of the Ganga River, and not all the vital parameters of river water quality, as claimed previously. ${ }^{29}$ Therefore, the statement that the COVID-19 pandemic improved all water quality parameters of the Ganga river is incorrect, and the different pollutants should be considered individually.

\section{ASSOCIATED CONTENT}

\section{SI Supporting Information}

The Supporting Information is available free of charge at https://pubs.acs.org/doi/10.1021/acs.estlett.0c00982.

Detailed information about the measurement protocols of IC and QQQ-ICP-MS and quality assurance and quality control, map of the study area (Figure S1), temporal variability of major ions, trace elements, precipitation, and discharge (Figure S2), $\mathrm{Ca} / \mathrm{Na}$ versus $\mathrm{Mg} / \mathrm{Na}$ molar ratio and $\mathrm{Ca} / \mathrm{Na}$ versus $(1000 \times \mathrm{Sr}) / \mathrm{Na}$ diagrams (Figure S3), $\mathrm{Rb}-, \mathrm{NO}_{3}{ }^{-}$, and $\mathrm{PO}_{4}{ }^{2-}$ normalized SoG plotted against Rb-normalized SoA, their temporal variability, and comparison with preCOVID-19 ratios (Figure S4), temporal trends of SoA and SoG normalized against $\mathrm{Na}$ and $\mathrm{Cl}$ (Figure S5), the effect of lockdown restrictions on the dissolved geogenic trace elements (Figure S6), time-series measurements of concentrations of dissolved major elements and trace elements, respectively (Tables $\mathrm{S} 1$ and $\mathrm{S} 2$ ), dissolved nitrate $\left(\mathrm{NO}_{3}{ }^{-}\right)$and phosphate $\left(\mathrm{PO}_{4}{ }^{3-}\right)$ concentrations (Table S3), correlation matrix of major ions and trace elements data (Table S4), and $\log (\mathrm{C})$ versus $\log (\mathrm{Q})$ relationship (Table S5) (PDF) 


\section{AUTHOR INFORMATION}

\section{Corresponding Author}

Indra S. Sen - Department of Earth Sciences, Indian Institute of Technology Kanpur, Kanpur, UP 208016, India;

๑ orcid.org/0000-0001-7302-2313; Email: isen@iitk.ac.in

\section{Authors}

Tanuj Shukla - Department of Earth Sciences, Indian Institute of Technology Kanpur, Kanpur, UP 208016, India

Soumita Boral - Department of Earth Sciences, Indian Institute of Technology Kanpur, Kanpur, UP 208016, India

Sanjeet Sharma - Department of Earth Sciences, Indian Institute of Technology Kanpur, Kanpur, UP 208016, India

Complete contact information is available at:

https://pubs.acs.org/10.1021/acs.estlett.0c00982

\section{Author Contributions}

I.S.S. conceived the study. S.S. did all of the field work. I.S.S., T.S., and S.B. did all of the data analysis. I.S.S. wrote the paper with input from T.S. and S.B.

\section{Notes}

The authors declare no competing financial interest.

\section{ACKNOWLEDGMENTS}

This work was supported by the Indo-U.S. Science and Technology Forum (IUSSTF/WAQM-Water Quality ProjectIIT Kanpur/2017) (I.S.S.). S.B. and T.S. are thankful for the $\mathrm{Ph} . \mathrm{D}$. and postdoctoral scholarships, respectively, from the Indian Institute of Technology Kanpur. The discussion with Bernhard Peucker-Ehrenbrink is greatly acknowledged. I.S.S. thanks Greg Friske for providing the rainfall data, as well as Bittu Sharma, Bharat Choudhury, Hirdesh Singh, and Manish Yadav for assistance during field trips and analysis. The authors also thank the editor and three anonymous reviewers for their constructive comments and arguments that have improved the overall quality of the work.

\section{REFERENCES}

(1) Hartmann, J.; et al. A Brief Overview of the GLObal RIver Chemistry Database, GLORICH. Procedia Earth Planet. Sci. 2014, 10, 23-27.

(2) Hartmann, J.; Lauerwald, R.; Moosdorf, N. L. Global river chemistry database. PANGAEA 2019, DOI: 10.1594/PANGAEA.902360.

(3) United Nations Environment Programme. GEMStat database of the Global Environment Monitoring System for Freshwater (GEMS/ Water) Programme; International Centre for Water Resources and Global Change: Koblenz, Germany, 2018 (retrieved from https:// gemstat.org, accessed 2020-09-20).

(4) United Nations Environment Programme. A Snapshot of the World's Water Quality: Towards a Global Assessment. 2016.

(5) UNEP-DHI and UNEP. Transboundary river basins: Status and trends. United Nations Environment Programme (UNEP): Nairobi, Kenya, 2016 (http://twap-rivers.org/assets/GEF_TWAPRB FullTechnicalReport compressed.pdf).

(6) Best, J. Anthropogenic stresses on the world's big rivers. Nat. Geosci. 2019, 12, 7-21.

(7) Paul, D. Research on heavy metal pollution of river Ganga: A review. Ann. Agrar. Sci. 2017, 15, 278-286.

(8) Milliman, J.; Farnsworth, K. River discharge to the coastal ocean: A global synthesis; Cambridge University Press: Cambridge, U.K., 2011.

(9) Bickle, M. J.; Tipper, E. D.; Galy, A.; Chapman, H.; Harris, N. On discrimination between carbonate and silicate inputs to Himalayan rivers. Am. J. Sci. 2015, 315 (2), 120-166.
(10) Bickle, M. J.; et al. Chemical weathering outputs from the flood plain of the Ganga. Geochim. Cosmochim. Acta 2018, 225, 146-175.

(11) Oliver, L.; et al. Silicate weathering rates decoupled from the ${ }^{87} \mathrm{Sr} /{ }^{86} \mathrm{Sr}$ ratio of the dissolved load during Himalayan erosion. Chem. Geol. 2003, 201 (1-2), 119-139.

(12) Harris, N.; Bickle, M.; Chapman, H.; Fairchild, I.; Bunbury, J. The significance of Himalayan rivers for silicate weathering rates: Evidence from the Bhote Kosi tributary. Chem. Geol. 1998, 144 (34), 205-220.

(13) Singh, S. K.; Trivedi, J. R.; Pande, K.; Ramesh, R.; Krishnaswami, S. Chemical and strontium, oxygen, and carbon isotopic compositions of carbonates from the Lesser Himalaya: Implications to the strontium isotope composition of the source waters of the Ganga, Ghaghara, and the Indus rivers. Geochim. Cosmochim. Acta 1998, 62 (5), 743-755.

(14) Dalai, T. K.; Singh, S. K.; Trivedi, J. R.; Krishnaswami, S. Dissolved rhenium in the Yamuna River System and the Ganga in the Himalaya: Role of black shale weathering on the budgets of Re, Os, and $\mathrm{U}$ in rivers and $\mathrm{CO}_{2}$ in the atmosphere. Geochim. Cosmochim. Acta 2002, 66 (1), 29-43.

(15) Galy, A.; France-Lanord, C. Weathering processes in the Ganges-Brahmaputra basin and the riverine alkalinity budget. Chem. Geol. 1999, 159 (1-4), 31-60.

(16) Lupker, M.; et al. A Rouse-based method to integrate the chemical composition of river sediments: Application to the Ganga basin. J. Geophys. Res. 2011, 116, 756.

(17) Sarin, M. M.; Krishnaswami, S. Major ion chemistry of the Ganga-Brahmaputra river systems, India. Nature 1984, 312 (5994), 538-541.

(18) Sarin, M. M.; Krishnaswami, S.; Dilli, K.; Somayajulu, B. L. K.; Moore, W. S. Major ion chemistry of the Ganga-Brahmaputra river system: weathering processes and fluxes to the Bay of Bengal. Geochim. Cosmochim. Acta 1989, 53, 997-1009.

(19) Lupker, M.; et al. Predominant floodplain over mountain weathering of Himalayan sediments (Ganga basin). Geochim. Cosmochim. Acta 2012, 84, 410-432.

(20) Rai, S. K.; Singh, S. K.; Krishnaswami, S. Chemical weathering in the plain and peninsular sub-basins of the Ganga: impact on major ion chemistry and elemental fluxes. Geochim. Cosmochim. Acta 2010, 74 (8), 2340-2355.

(21) Tripathy, G. R.; Goswami, V.; Singh, S. K.; Chakrapani, G. J. Temporal variations in $\mathrm{Sr}$ and $87 \mathrm{Sr} / 86 \mathrm{Sr}$ of the Ganga headwaters: estimates of dissolved $\mathrm{Sr}$ flux to the mainstream. Hydrol. Processes 2010, 24 (9), 1159-1171.

(22) Ministry of Environment, Forest, and Climate Change, Government of India. Environment (Protection) Amendment Rules. 2017 (http://moef.gov.in/wp-content/uploads/2017/11/Petcoke. pdf).

(23) Singh, S. K.; Rai, J. P. N. Pollution studies on River Ganga in Allahabad District. Pollut. Res. 2003, 22, 469-472.

(24) Mishra, A. Assessment of water quality using principal component analysis: a case study of the River Ganges. J. Wat. Chem. Technol. 2010, 32, 227-234.

(25) Birol, E.; Das, S. Estimating the value of improved wastewater treatment: the case of River Ganga, India. J. Environ. Manage. 2010, 91, 2163-2171.

(26) ENVIS Centre on Hygiene, Sanitation, Sewage Treatment Systems, and Technology. National status of waste water generation and treatment. 2019 (www.sulabhenvis.nic.in/Database/STST_ wastewater_2090.aspx).

(27) Sharma, Y. Case Study I: The Ganga, India. In Water Pollution Control - A Guide to the Use of Water Quality Management Principles; Helmer, R., Hespanhol, I., Eds.; published on behalf of the United Nations Environment Programme, Water Supply \& Sanitation Collaborative Council, and World Health Organization by E. \& F. Spon, 2009.

(28) Patel, P. P.; Mondal, S.; Ghosh, K. G. Some respite for India's dirtiest river? Examining the Yamuna's water quality at Delhi during 
the COVID-19 lockdown period. Sci. Total Environ. 2020, 744, 140851.

(29) Dutta, V.; Dubey, D.; Kumar, S. Cleaning the River Ganga: Impact of lockdown on water quality and future implications on river rejuvenation strategies. Sci. Total Environ. 2020, 743, 140756.

(30) Trivedi, R. C. Water quality of the Ganga River-an overview. Aquat. Ecosyst. Health Manage. 2010, 13 (4), 347-351.

(31) Boral, S.; Sen, I. S.; Tripathi, A.; Sharma, B.; Dhar, S. Tracking dissolved trace and heavy metals in the ganga river from source to sink: A baseline to judge future changes. Geochem., Geophys., Geosyst. 2020, 21, e2020GC009203.

(32) Status of grossly polluting industries. National Mission Clean Ganga (https://nmcg.nic.in/pdf/pollution\%20assessment.pdf).

(33) Cohen, S.; Kettner, A. J.; Syvitski, J. P.; Fekete, B. M. WBMsed, a distributed global-scale riverine sediment flux model: Model description and validation. Comput. Geosci. 2013, 53, 80-93.

(34) Brakenridge, G. R.; et al. River and Reservoir Watch Version 3.5, Experimental Satellite-Based River Discharge and Reservoir Area Measurements: Technical Summary. 2016 (http://floodobservatory. colorado.edu/technical.html).

(35) Funk, C. C.; et al. A quasi-global precipitation time series for drought monitoring. U.S. Geological Survey Data Series 2014, 832 (4), $1-12$.

(36) Choi, H.-B.; Ryu, J.-S.; Shin, W.-J.; Vigier, N. The impact of anthropogenic inputs on lithium content in river and tap water. Nat. Commun. 2019, 10, No. 5371.

(37) Sen, I. S.; Peucker-Ehrenbrink, B. Anthropogenic disturbance of element cycles at the Earth's surface. Environ. Sci. Technol. 2012, 46 (16), 8601-8609.

(38) Gaillardet, J.; Viers, J.; Dupré, B. Trace Elements in River Waters. In Treatise on Geochemistry, 2nd ed.; Drever, J. I., Ed.; Elsevier, 2014; pp 195-235.

(39) Tipper, E. T.; et al. Global silicate weathering flux overestimated because of sediment-water cation exchange. Proc. Natl. Acad. Sci. U. S. A. 2021, 118 (1), e2016430118.

(40) Baronas, J. J.; Torres, M. A.; Clark, K. E.; West, A. J. Mixing as a driver of temporal variations in river hydrochemistry: Major and trace element concentration dynamics in the Andes-Amazon transition. Water Resour. Res. 2017, 53, 3120-3145.

(41) Godsey, S. E.; Kirchner, J. W.; Clow, D. W. Concentrationdischarge relationships reflect chemostatic characteristics of US catchments. Hydrol. Processes 2009, 23, 1844-1864.

(42) Boral, B. Controls on short-term dissolved ${ }^{87} \mathrm{Sr} /{ }^{86} \mathrm{Sr}$ variations in large rivers: Evidence from the Ganga-Brahmaputra. Earth Planet Sci. Lett., 2021, manuscript submitted for publication.

(43) Gaillardet, J.; Dupré, B.; Louvat, P.; Allegre, C. J. Global silicate weathering and $\mathrm{CO}_{2}$ consumption rates deduced from the chemistry of large rivers. Chem. Geol. 1999, 159 (1-4), 3-30. 